\title{
Effectiveness of Strategy, ES Seven Cognitive and learn swimmers crawling on the abdomen and back
}

\section{Dr/ Rasha Mohamed Tawfiq}

Introduction and research problem

Education in Egypt is now linked to the transition to the future, from negative education to positive education, from the role of teacher to the role of active intermediary, and countries are playing an important role in leading the educational process, financing and control, and the society became a partner. (Teachers, learners, curricula, methods and methods of teaching), thus affecting the transformation of each educational institution into a center of radiation to discharge experiences, abilities, talents and skills.

The time has come for all the workers in the field of education to unite in order to benefit the modern Egypt and its credibility, leaving the focus on conservation, teaching and traditional methods of teaching that are not in line with the requirements of the age, focusing on educational strategies and modern teaching methods in order to prepare the citizen for productive work, Creative and creative (20:

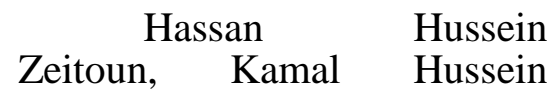

Zeitoun (2003), states that the model of constructive learning is designed to link science to culture and society and seeks to help students build their scientific concepts and knowledge through four stages drawn from the three stages of learning (concept exploration, The four stages are the advocacy phase, the exploration phase, and the stage of proposing interpretations, solutions, and decision-making stages (4: 440)

It also shows that the model of constructive learning aims to make the student the focus of the educational process, he discusses the problem and collect the information he sees may contribute to the solution of the problem and then discuss the proposed solutions with colleagues, and then study the possibility of applying these solutions in a scientific manner and the student in accordance with this philosophy,

$$
\text { Through his }
$$
practice of scientific thinking, he is a researcher of the concerned, in

\section{Assiut Journal For Sport Science Arts}


addition to the fact that he builds his knowledge and participates in the responsibility of learning management and evaluation, he is more active, researcher and prospector to discover the appropriate solutions to the problems he faces, the focus of this model and his focus, It is a structured learning environment, a backup source for information if necessary, a model from which the student gains experience to observe first, and then assigns them some tasks before and under careful observation. Learning in collaboration with them, thus contributing to the process of learning management and evaluation (16: 11-18) (47:29)

In this regard, Khairi Al-Maghazi, Badir Ajaj (2000), Zeinab Omar, and Wafa Mafraj (2009) point out that in the model of constructive learning, students are helped to build their scientific concepts and knowledge. This model emphasizes linking science to culture and society. (108,107: 5) (7) The path of the lesson is one and the interaction between the two sides is very important. : 438-441

At the beginning of the third millennium, it was found that students' reality necessitates the use of modern methods of learning that combine them with the psychosocial needs of students, and develop the desired behaviors, which are most needed in their dealings within the classroom and in the community. Modern methods in the learning process, including the seven-stage learning cycle. (6: 9) (74:12)

The seven-stage

learning dimensions model or the Seven E's constructivist model is one of the modern structural models, the teaching method used in the Seven E's constructivist model, or the seven-stage learning dimensions course, which includes seven steps: Excitement, And to stimulate their curiosity, Exploration, and the aim of this step and satisfy the curiosity by providing experiences for pupils and cooperation to understand the meaning of the concept, Explanation / Explaination, the purpose of this step is to clarify the concept and definition of terminology, expansion (expansion thinking) The purpose of this step is to clarify the relationship between the concept and other concepts, exchange, change, Exchanging, the purpose of 
this step is to share ideas or experiences, the Exam Examination, the purpose of this step is to assess the learning and understanding of pupils. (27: 56-59)

Swimming is an important foundation for the practice of aquatic sports. It is one of the individual games that need to be mastered to a clear vision of the form of learning and learning swimming, using some technological applications on learning products for swimming methods, which requires the efforts of the teaching staff and new tasks. For implementation, the teacher became a designer and programmer in addition to being a teacher, as well as the learner has become a positive role in the interaction with the elements of the educational situation. (90:10)

The educational

environment of the university stage requires teaching staff to make double efforts due to the high age of education for students. This stage does not include some physical, psychological and psychological problems, which necessitated taking care of all factors that help to improve the skill level of the student and keep abreast of modern techniques.
Modern and appropriate capabilities of students, and the most efficient methods and methods of teaching the most economical and time. (90:10)

To the best of the reader's knowledge, and through reading and reading on many previous studies, I found that the model of the course dimensions learning 7, ES modified structural and did not address one of the researchers to use in learning swimmers crawling on the abdomen and back, and the results of these studies and studies on the role played by the large This model is a success in the educational process. This research is an attempt to identify the effect of the use of the modified learning course on the level of learning some swimmers to crawl the back abdomen and stimulate the learner to learn more and increase the efficiency of the teaching and learning process.

\section{Research goal}

Identify

the

effectiveness of the use of modified structural ES strategy 7 on the level of cognitive achievement and learn swimmers crawling on the abdomen and back.

Research hypotheses

-There are statistically significant differences between the averages of Assiut Journal For Sport Science Arts 
preand post measurements in the level of cognitive achievement and the learning of swimmers on the abdomen and back in the experimental group.

-There are statistically significant differences between the averages of preand post measurements in the level of cognitive achievement and the learning of swimmers on the abdomen and back in the students of the control group.

-There are statistically significant differences between the two dimensions of the two dimensional measurements in the experimental and control research groups. The level of cognitive achievement and the learning of the swimmers on the abdomen and back and in favor of the experimental research group.

\section{Some terms in the search}

Learning Dimensions Course 7, ES Structural Adjustment Seven E's:

Is an educational model consisting of seven teaching steps used by the teacher with his students in the lesson and aims to build the student scientific knowledge himself, in addition to the development of many different concepts and skills and relies on this model of excitement and curiosity and exploration and interpretation and expansion and linking concepts and some modification and misconceptions and have them (25: 152)

Research Plan and Procedures:

\section{Research Methodology:}

The researcher used the experimental method due to its relevance to the nature of the current research using the experimental design of two groups, one experimental and the other controlling following the preand post measurement of both groups.

Community and Sample Search:

Such as the research society students of the Faculty of Physical Education University of Port Said during the academic year 2016/2016 The first semester has reached the research community (46) student, and the researcher chose the random sample of the students of the second division Water Sports Course (2) (30) students from the research community and were divided into two equal groups, one experimental (15) students and uses the model of learning building 7. ES in the level of

\section{Assiut Journal For Sport Science Arts}


cognitive achievement and learn swimmers crawling on the abdomen and back, and the other 15 female student uses the traditional method based on Play And the model in learning swimmers crawling on the abdomen and back in search, in addition to (16) students to conduct the exploratory study of the research community and outside the basic research sample.

Prevalence of frequency distribution and equivalence of sample members:

(1),(2) shows the frequency distribution and equivalence between the two groups.

Table (1)

Statistical profile of the research sample in the variables of age, height and weightThe level of skill of the swimmers crawl on the abdomen and back and cognitive achievement $N=46$

\begin{tabular}{|c|c|c|c|c|c|c|c|}
\hline Serial & \multicolumn{2}{|c|}{ Variables } & $\begin{array}{c}\text { measruing } \\
\text { unit }\end{array}$ & SMA & $\begin{array}{l}\text { standard } \\
\text { deviation }\end{array}$ & Mediator & $\begin{array}{c}\text { Torsion } \\
\text { coefficient }\end{array}$ \\
\hline 1 & \multicolumn{2}{|l|}{ Age } & Year & 19.20 & 0.98 & 19.00 & 0.612 \\
\hline 2 & \multicolumn{2}{|l|}{ Highet } & $\mathrm{Cm}$ & 168.17 & 3.15 & 168.0 & 0.001 \\
\hline 3 & \multicolumn{2}{|l|}{ weight } & Kgm & 67.12 & 2.88 & 67.00 & 0.125 \\
\hline 4 & \multirow{4}{*}{$\begin{array}{l}\text { Swimmin } \\
\mathrm{g} \text { crawl } \\
\text { on the } \\
\text { abdomen }\end{array}$} & $\begin{array}{l}\text { Foot } \\
\text { strikes }\end{array}$ & Degree & 4.12 & 0.81 & 4.10 & 0.25 \\
\hline 5 & & $\begin{array}{l}\text { Arms } \\
\text { movements }\end{array}$ & Degree & 4.15 & 0.22 & 4.15 & 0.14 \\
\hline 6 & & $\begin{array}{l}\text { Compatibili } \\
\text { ty and } \\
\text { breathing }\end{array}$ & Degree & 4.20 & 0.28 & 4.25 & 0.32 \\
\hline 7 & & $\begin{array}{l}\text { total } \\
\text { summation }\end{array}$ & Degree & 12.47 & 0.64 & 12.50 & 0.36 \\
\hline 8 & \multirow{4}{*}{$\begin{array}{l}\text { swimmin } \\
\text { g } \\
\text { Back }\end{array}$} & Foot strikes & Degree & 4.14 & 0.22 & 4.10 & 0.145 \\
\hline 9 & & $\begin{array}{l}\text { Arms } \\
\text { movements }\end{array}$ & Degree & 4.11 & 0.15 & 4.10 & 0.32 \\
\hline 10 & & $\begin{array}{l}\text { Compatibility } \\
\text { and breathing }\end{array}$ & Degree & 4.18 & 0.13 & 4.15 & 0.25 \\
\hline 11 & & $\begin{array}{l}\text { total } \\
\text { summation }\end{array}$ & Degree & 12.43 & 0.58 & 12.35 & 0.17 \\
\hline 12 & \multicolumn{2}{|c|}{ Cognitive Achievement } & Degree & 30.55 & 2.94 & 30.90 & 0.357 \\
\hline
\end{tabular}

It is clear from Table (1) that the values of torsion coefficients for the growth rates and the technical variables of swimming (crawling on the abdomen and back) and the cognitive achievement of the study sample are limited to \pm 3 , indicating the moderation of the distribution of female students in these variables. 
-Equal sample search:

Table (2)

"The significance of statistical differences between the control and experimental groups in each of the growth ratesAnd the technical variables and cognitive achievement of the sample in question" $N=1$ n = 15

\begin{tabular}{|c|c|c|c|c|c|c|c|c|}
\hline \multirow{2}{*}{\multicolumn{2}{|c|}{ Variables }} & \multirow[t]{2}{*}{$\begin{array}{c}\text { measruing } \\
\text { unit }\end{array}$} & \multicolumn{2}{|c|}{$\begin{array}{c}\text { The } \\
\text { experimental } \\
\text { group } \\
(\mathbf{N}=15)\end{array}$} & \multicolumn{2}{|c|}{$\begin{array}{l}\text { Control } \\
\text { group } \\
(\mathbf{N}=15)\end{array}$} & \multirow[t]{2}{*}{$\begin{array}{c}\text { Calculated } \\
\text { value (t) }\end{array}$} & \multirow[t]{2}{*}{$\begin{array}{c}\text { Statistical } \\
\text { significance }\end{array}$} \\
\hline & & & $\mathrm{M}$ & $\mathrm{E}$ & $\mathrm{M}$ & $E$ & & \\
\hline \multicolumn{2}{|l|}{ Age } & Year & 19.12 & 1.12 & 19.15 & $\begin{array}{l}1.1 \\
8\end{array}$ & 0.11 & $\begin{array}{l}\text { Non } \\
\text { signfibnce }\end{array}$ \\
\hline \multicolumn{2}{|l|}{ Highet } & $\mathrm{Cm}$ & 166.90 & 2.18 & $\begin{array}{l}167.1 \\
0\end{array}$ & $\begin{array}{l}2.6 \\
5\end{array}$ & 0.25 & $\begin{array}{l}\text { Non } \\
\text { signfibnce }\end{array}$ \\
\hline \multicolumn{2}{|l|}{ weight } & Kgm & 66.15 & 1.99 & 66.98 & $\begin{array}{l}1.4 \\
7\end{array}$ & 0.14 & $\begin{array}{l}\text { Non } \\
\text { signfibnce }\end{array}$ \\
\hline \multirow{4}{*}{$\begin{array}{l}\text { Swimmin } \\
\mathrm{g} \quad \text { crawl } \\
\text { on the } \\
\text { abdomen }\end{array}$} & Foot strikes & Degree & 4.10 & 0.15 & 4.11 & $\begin{array}{l}0.1 \\
7\end{array}$ & 0.32 & $\begin{array}{l}\text { Non } \\
\text { signfibnce }\end{array}$ \\
\hline & $\begin{array}{l}\text { Arms } \\
\text { movements }\end{array}$ & Degree & 4.16 & 0.32 & 4.14 & $\begin{array}{l}0.1 \\
6\end{array}$ & 0.51 & $\begin{array}{l}\text { Non } \\
\text { signfibnce }\end{array}$ \\
\hline & $\begin{array}{l}\text { Compatibili } \\
\text { ty and } \\
\text { breathing }\end{array}$ & Degree & 4.21 & 0.14 & 4.13 & $\begin{array}{l}0.1 \\
2\end{array}$ & 0.87 & $\begin{array}{l}\text { Non } \\
\text { signfibnce }\end{array}$ \\
\hline & $\begin{array}{l}\text { total } \\
\text { summation }\end{array}$ & Degree & 12.47 & 0.66 & 12.38 & $\begin{array}{l}0.9 \\
1\end{array}$ & 0.36 & $\begin{array}{l}\text { Non } \\
\text { signfibnce }\end{array}$ \\
\hline \multirow{4}{*}{$\begin{array}{l}\text { swimmin } \\
\text { g } \\
\text { Back }\end{array}$} & Foot strikes & Degree & 4.15 & 0.21 & 4.13 & $\begin{array}{ll}0.1 \\
7\end{array}$ & 0.54 & $\begin{array}{l}\text { Non } \\
\text { signfibnce }\end{array}$ \\
\hline & $\begin{array}{l}\text { Arms } \\
\text { movements }\end{array}$ & Degree & 4.13 & 0.15 & 4.12 & ${ }_{2}^{0.3}$ & 0.25 & $\begin{array}{l}\text { Non } \\
\text { signfibnce }\end{array}$ \\
\hline & $\begin{array}{l}\text { Compatibili } \\
\text { ty and } \\
\text { breathing }\end{array}$ & Degree & 4.17 & 0.11 & 4.15 & $\begin{array}{ll}0.1 \\
4\end{array}$ & 0.63 & $\begin{array}{l}\text { Non } \\
\text { signfibnce }\end{array}$ \\
\hline & $\begin{array}{l}\text { total } \\
\text { summation }\end{array}$ & Degree & 12.45 & 1.12 & 12.40 & $\begin{array}{ll}0.6 \\
4\end{array}$ & 0.47 & $\begin{array}{l}\text { Non } \\
\text { signfibnce }\end{array}$ \\
\hline \multicolumn{2}{|c|}{ Cognitive Achievement } & Degree & 28.54 & 1.19 & 29.50 & $\begin{array}{l}1.2 \\
8\end{array}$ & 0.54 & $\begin{array}{l}\text { Non } \\
\text { signfibnce }\end{array}$ \\
\hline
\end{tabular}

*The value of $(\mathrm{t})$ tabular at the level of significance $(0.05)=1.697$

Table (2) shows that there growth rates, the technical are no statistically variables and the cognitive significant differences achievement level of the between the control and sample in question. 0.05) experimental research indicating their equivalence groups in each of the in those variables.

Assiut Journal For Sport Science Arts 
Data collection tools and means:

\section{A: Tools and devices}

-Resistameter for measuring length in centimeters.

-Medical balance to measure weight in kilograms.

-Swimming Instruction

Tools (Floating Panels Flippers -Plams - Floats)

B: Tests used in research:

1-Test the level of skilled performance: The level of skill performance was measured by students of the second division of the Faculty of Physical Education, Port Said University for the prescribed skills (swimming crawling on the abdomen back swimming) through a committee composed of (3) arbitrators members of the faculty of water sports and vacations at the faculties of education Sports Zagazig University and their names attached (1) Each skill of swimming skills was assessed crawling on the abdomen and back

(Blows of the two legs, arms movements, compatibility and breathing) of 6 degrees and the total score for each swimmer crawling on the abdomen, back swimming (18 degrees) Learning Dimensions Course 7, ES Modified Structural:

The researcher used the model of the course of learning of modified structural constructs, as indicated by Amira Mohammed Amir (2011), Hossam El-Din Nabih Abdel-Fattah (2005), Rasha Najah Ali (2013) (2001), 8 which consisted of the following steps:

$$
\text { Implementation of }
$$

the work using the learning dimensions course model 7 , ES Modified Structural:

The basic stages of the ESD 7 model have been taken into consideration as follows:

* Stage of stimulation (activation):

At this stage, the researcher stimulated the students and aroused their curiosity and interest in a particular subject through dialogue with them about the importance of these skills 
and how they performed and points of construction with the legal aspects of the skill and performance of the model and the presentation of some slides of skill.

\section{* Phase of exploration:}

At this stage, the researcher satisfied the curiosity and curiosity in the students by providing experience to him to understand how the performance, in which the final form of the skill is detected by displaying the skill through the images of education or performance by a student with a good level of swimming in order to try to acquire the steps Sound for performance and try to draw this image into her mind.

* Phase of Interpretation (Illustration):

At this stage the researcher explained and explained the skill to be learned and try to shed light on the technical points affecting the skill in question.

\section{* Expansion phase:}

At this stage, the researcher supervised the method of performance of the skills in question and linking the skills to each other and find the logical sequence of skill and try to perform correctly without intervention by the researcher.

* Extension phase:

At this stage the researcher supervised the students during their performance skills and clarify the relationship and linking skills and some.

* Exchange phase:

View and discuss the results:

First: Display the results 
Table (3)

"The significance of the differences between the preand post measurement in the level of skill performance of the two)

Crawling on the abdomen - back) experimental research group

"N $=15$

\begin{tabular}{|c|c|c|c|c|c|c|c|c|c|c|}
\hline & \multirow{2}{*}{ Variables } & \multirow{2}{*}{$\begin{array}{c}\text { measr } \\
\text { uing } \\
\text { unit }\end{array}$} & \multicolumn{2}{|c|}{$\begin{array}{c}\text { Pre } \\
\text { measurement }\end{array}$} & \multicolumn{2}{|c|}{$\begin{array}{c}\text { Post } \\
\text { measurem } \\
\text { ent }\end{array}$} & \multirow{2}{*}{$\begin{array}{c}\text { Differe } \\
\text { nces } \\
\text { betwee } \\
n \text { the } \\
\text { two } \\
\text { averag } \\
\text { es }\end{array}$} & \multirow{2}{*}{$\begin{array}{c}\text { Improve } \\
\text { ment } \\
\text { rate }\end{array}$} & \multirow{2}{*}{$\begin{array}{l}\text { Calcul } \\
\text { ated } \\
\text { value } \\
(t)\end{array}$} & \multirow{2}{*}{$\begin{array}{l}\text { Statistical } \\
\text { significance }\end{array}$} \\
\hline & & & $\mathbf{M}$ & $\mathbf{E}$ & $\mathbf{M}$ & $\mathbf{E}$ & & & & \\
\hline \multirow{4}{*}{$\begin{array}{l}\text { Swim } \\
\text { ming } \\
\text { crawl } \\
\text { on the } \\
\text { abdom } \\
\text { en }\end{array}$} & $\begin{array}{l}\text { Foot } \\
\text { strikes }\end{array}$ & Degree & 4.10 & 0.15 & 5.18 & 0.54 & 1.08 & $26.34 \%$ & 4.90 & signfibnce \\
\hline & $\begin{array}{l}\text { Arms } \\
\text { movem } \\
\text { ents }\end{array}$ & Degree & 4.16 & 0.32 & 5.19 & 0.12 & 1.03 & $24.75 \%$ & 4.62 & signfibnce \\
\hline & $\begin{array}{l}\text { Compat } \\
\text { ibility } \\
\text { and } \\
\text { breathi } \\
\text { ng }\end{array}$ & Degree & 4.21 & 0.14 & 5.17 & 0.25 & 0.98 & $23.27 \%$ & 4.87 & signfibnce \\
\hline & $\begin{array}{l}\text { total } \\
\text { summat } \\
\text { ion }\end{array}$ & Degree & 12.47 & 0.66 & 15.54 & 0.24 & 3.07 & $24.61 \%$ & 4.36 & signfibnce \\
\hline \multirow[t]{4}{*}{$\begin{array}{l}\text { swimm } \\
\text { ing }\end{array}$} & $\begin{array}{l}\text { Foot } \\
\text { strikes }\end{array}$ & Degree & 4.15 & 0.21 & 5.19 & 0.14 & 1.04 & $25.06 \%$ & 4.87 & signfibnce \\
\hline & $\begin{array}{l}\text { Arms } \\
\text { movem } \\
\text { ents }\end{array}$ & Degree & 4.13 & 0.15 & 5.15 & 0.36 & 1.02 & $24.69 \%$ & 4.36 & signfibnce \\
\hline & $\begin{array}{l}\text { Compat } \\
\text { ibility } \\
\text { and } \\
\text { breathi } \\
\text { ng }\end{array}$ & Degree & 4.17 & 0.11 & 5.13 & 0.14 & 0.96 & $23.02 \%$ & 4.24 & signfibnce \\
\hline & $\begin{array}{l}\text { total } \\
\text { summat } \\
\text { ion }\end{array}$ & Degree & 12.45 & 1.12 & 15.47 & 0.15 & 3.02 & $24.25 \%$ & 4.74 & signfibnce \\
\hline \multicolumn{2}{|c|}{$\begin{array}{l}\text { Cognitive } \\
\text { Achievement }\end{array}$} & Degree & 28.54 & 1.19 & 42.5 & 2.18 & 13.98 & $48.98 \%$ & 4.81 & signfibnce \\
\hline
\end{tabular}

-Tabular value at the level of significance $(0.05)=1.753$

Assiut Journal For Sport Science Arts 
It is clear from

Table (3) that there are statistically significant differences between the averages of the pre and post measurements at the level of some technical variables of swimming (crawling on the abdomen and back) in the second group (experimental group). The table value of (4.12) 4.90), which is greater than the tabular value at the significance level (0.05).At

\section{Table (4)}

"The significance of the differences between the pre and post measurement in the level of skill performance of my swim (Crawling on the abdomen - back) in the control research group" $\mathrm{N}=\mathbf{1 5}$

\begin{tabular}{|c|c|c|c|c|c|c|c|c|c|c|}
\hline \multirow{2}{*}{\multicolumn{2}{|c|}{ Variables }} & \multirow{2}{*}{$\begin{array}{c}\text { measruing } \\
\text { unit }\end{array}$} & \multicolumn{2}{|c|}{$\begin{array}{c}\text { Pre } \\
\text { measurement }\end{array}$} & \multicolumn{2}{|c|}{$\begin{array}{c}\text { Post } \\
\text { measurement }\end{array}$} & \multirow{2}{*}{$\begin{array}{c}\text { Differences } \\
\text { between } \\
\text { the two } \\
\text { averages }\end{array}$} & \multirow{2}{*}{$\begin{array}{l}\text { Improvement } \\
\text { rate }\end{array}$} & \multirow{2}{*}{$\begin{array}{l}\text { Calculated } \\
\text { value }(t)\end{array}$} & \multirow{2}{*}{$\begin{array}{c}\text { Statistical } \\
\text { significance }\end{array}$} \\
\hline & & & $\mathrm{m}$ & $\mathrm{E}$ & M & $\Pi$ & & & & \\
\hline \multirow{4}{*}{$\begin{array}{l}\text { Swimming } \\
\text { crawl }\end{array}$} & Foot strikes & Degree & 4.11 & 0.17 & 4.90 & 0.54 & 0.79 & $19.22 \%$ & 3.99 & signfibnce \\
\hline & $\begin{array}{l}\text { Arms } \\
\text { movements }\end{array}$ & Degree & 4.14 & 0.16 & 4.98 & 0.154 & 0.84 & $20.28 \%$ & 3.57 & signfibnce \\
\hline & $\begin{array}{l}\text { Compatibility } \\
\text { and breathing }\end{array}$ & Degree & 4.13 & 0.12 & 4.95 & 0.32 & 0.82 & $19.54 \%$ & 3.58 & signfibnce \\
\hline & $\begin{array}{l}\text { total } \\
\text { summation }\end{array}$ & Degree & 12.38 & 0.91 & 14.83 & 0.25 & 2.45 & $19.78 \%$ & 3.24 & signfibnce \\
\hline \multirow{4}{*}{$\begin{array}{l}\text { Swimming } \\
\text { crawl on } \\
\text { the back }\end{array}$} & Foot strikes & Degree & 4.13 & 0.17 & 4.88 & 0.54 & 0.75 & $18.15 \%$ & 3.98 & signfibnce \\
\hline & $\begin{array}{l}\text { Arms } \\
\text { movements }\end{array}$ & Degree & 4.12 & 0.32 & 4.90 & 0.32 & 0.78 & $18.93 \%$ & 3.15 & signfibnce \\
\hline & $\begin{array}{l}\text { Compatibility } \\
\text { and breathing }\end{array}$ & Degree & 4.15 & 0.14 & 4.98 & 0.14 & 0.83 & $20 \%$ & 3.98 & signfibnce \\
\hline & $\begin{array}{l}\text { total } \\
\text { summation } \\
\end{array}$ & Degree & 12.40 & 0.64 & 14.76 & 0.15 & 2.36 & $19.03 \%$ & .3 .87 & signfibnce \\
\hline \multicolumn{2}{|c|}{ Cognitive Achievement } & Degree & 29.50 & 1.28 & 34.25 & 0.98 & 4.75 & $16.10 \%$ & 3.88 & signfibnce \\
\hline
\end{tabular}

- Tabular value at the level of significance $(0.05)=1.753$

Table 4 shows averages of the preand post statistically significant measurements at the level differences between the of some of the technical this stage the researcher supervised the students during the exchange of ideas and experiences or change and collect interesting participation through various activities.

* Exam (eavaluation ):

At this stage, the researcher evaluated the performance of the students in the skills in question through direct observation of performance within the swimming pool. 
variables of swimming (crawling on the abdomen and back) of the controlled control group where the value of ( $\mathrm{T})$ was between (2.74 to 3.99$)$ The scale is at the significance level 0.05 .

Table (5)

"Significance of differences between the two dimensions in the experimental and control groups in the level of skill performance of swimming (crawling on the abdomen - back) $N=1 \quad n=15$

\begin{tabular}{|c|c|c|c|c|c|c|c|c|}
\hline \multicolumn{2}{|c|}{ Variables } & \multirow{3}{*}{$\begin{array}{c}\begin{array}{c}\text { measruing } \\
\text { unit }\end{array} \\
\text { Degree }\end{array}$} & \multicolumn{2}{|c|}{$\begin{array}{c}\text { The } \\
\text { experimental } \\
\text { group } \\
\end{array}$} & \multicolumn{2}{|c|}{$\begin{array}{l}\text { Control } \\
\text { group }\end{array}$} & \multirow{3}{*}{$\begin{array}{c}\begin{array}{c}\text { Calculated } \\
\text { value (t) }\end{array} \\
3.80\end{array}$} & \multirow{3}{*}{$\begin{array}{c}\begin{array}{c}\text { Statistical } \\
\text { significance }\end{array} \\
\text { Significantly }\end{array}$} \\
\hline & & & \multirow{2}{*}{$\frac{\mathbf{M}}{5.18}$} & \multirow{2}{*}{$\frac{\mathbf{E}}{\overline{0.54}}$} & \multirow{2}{*}{$\frac{\mathbf{M}}{24.90}$} & \multirow{2}{*}{ 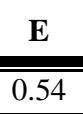 } & & \\
\hline Swimmin & Foot strikes & & & & & & & \\
\hline & $\begin{array}{l}\text { Arms } \\
\text { movements }\end{array}$ & Degree & 5.19 & 0.12 & 4.98 & 0.154 & 3.56 & Significantly \\
\hline & $\begin{array}{l}\text { Compatibili } \\
\text { ty and } \\
\text { breathing }\end{array}$ & Degree & 5.17 & 0.25 & 4.95 & 0.32 & 3.67 & Significantly \\
\hline & $\begin{array}{l}\text { total } \\
\text { summation }\end{array}$ & Degree & 15.54 & 0.24 & 14.83 & 0.25 & 3.47 & Significantly \\
\hline \multirow{4}{*}{\begin{tabular}{l}
\multicolumn{3}{l}{ Swimmin } \\
$\mathrm{g} \quad$ crawl \\
on the \\
back
\end{tabular}} & Foot strikes & Degree & 5.19 & 0.14 & 4.88 & 0.54 & 3.62 & Significantly \\
\hline & $\begin{array}{l}\text { Arms } \\
\text { movements }\end{array}$ & Degree & 5.15 & 0.36 & 4.90 & 0.32 & 3.15 & Significantly \\
\hline & $\begin{array}{l}\text { Compatibili } \\
\text { ty and } \\
\text { breathing }\end{array}$ & Degree & 5.13 & 0.14 & 4.98 & 0.14 & 3.84 & Significantly \\
\hline & $\begin{array}{l}\text { total } \\
\text { summation }\end{array}$ & Degree & 15.47 & 0.15 & 14.76 & 0.15 & 3.15 & Significantly \\
\hline \multicolumn{2}{|c|}{ Cognitive Achievement } & Degree & 42.52 & 2.18 & 34.25 & 0.98 & 3.18 & Significantly \\
\hline
\end{tabular}

-The value of $(\mathrm{t})$ the table at the level of significance $(0.05)=1.697$

Table

(5)

shows

statistically

significant

differences between mean

distance measurements in the experimental and control groups in the level of skill performance of the crawling on the abdomen and back. The table value of (3.15 to 3.84) is greater than its value The scale is at the significance level (0.05)

Second: Discuss the results

Table 3 shows statistically significant differences between the averages of preand post measurements in the performance level of the two cultivars (crawling on the 
abdomen and back) in the experimental group where the tabular value of (4.12 to 4.90) is greater than its value $(0.05)$. The improvement was due to the use of the proposed program of seven-stage ES7, which improved the cognitive aspects of the experimental group, which led to an improvement in the skill level of the crawling knees on the abdomen and back.

The researcher returns the progress of the experimental group in the level of skill performance of the crawlers on the abdomen and back due to the model of the seven-stage learning cycle, ES 7, which consists of seven stages for the transition to a stage only after passing the previous stage, where the students are excited to learn and satisfy For curiosity by exploration and then explain and clarify what they discovered, and applied in the swimming pool and linking with the skills already learned and then exchange ideas and experiences under the supervision of the researcher who is the assessment to help students to learn on their own and to achieve the best performance, (2014) indicates that the learning cycle develops learners' ability to learn better (24:15)

The researcher traces the progress made by the experimental group that used the educational program using the role model of the dimensions of learning seven stages, as it encouraged the students to good scientific thinking as well as the development of self-direction attempts to learn skills, and it provokes the student's thinking and works to thrill and make positive and also helped Creating an atmosphere of attention and attention in the students, and the steps of teaching according to this method allows students to think and interpret cases and extract information and knowledge, and then apply what has been learned, which prompts students to curiosity and increase the level of This is in line with the results of the studies of "Ali Abdul Majid" (2000), (13), Omar Abdullah (2004) (14), and) Showed positive progress for groups that used the seven-stage learning cycle to learn about knowledge and collect information in the samples under their research. 
In this regard, Jabir Abdul Hamid (2006) noted that the seven-stage learning dimensions model provides an opportunity for learners to think, search for and know information, thus helping them to solve the problems that they may face. (2: 58)

The reason for the progress of the experimental group's students is that the learning program using the seven-stage learning dimensions model was positive and effective in the level of cognitive achievement, such as crawling on the abdomen and back, and believes that the formation of knowledge and access to information was formed by students in that group through their thinking and activity The ideas between the students of one group and between the groups as a whole, in addition to the fact that the communication between the students in the cooperative group leads to increased effectiveness in the search for information, which is reflected in the cycle of increasing achievement and not forgetting the scientific material and in The group discussions lead to the retrieval of information among students. This leads to a deeper understanding of information in terms of the fact that active learning is based on knowledge through interaction with information and with the experiences of others, not through the formation of images or copies of reality, as well as that the learner builds his own knowledge.

The results also agree with the results of studies that dealt with the role played by some strategies and models of structural theory in the field of cognitive achievement of some sports activities, which was positive and led to the progress of learners in this field of knowledge, which illustrates the important role of this theory in building the knowledge of the learner in sports activities These studies include the study of the toxicity of Mustafa (2001) (9), Aisha Mohammed Al-Fateh (2005) (11), thus validating the validity of the research, which provides that there are differences statistically significant between the averages of preand post measurements in the level of cognitive achievement and learning some Basic skills Yeh swimming in the experimental research group students. 
Table 4 shows statistically significant differences between the averages of preand post measurements at the level of some technical variables of swimming (crawling on the abdomen - crawling on the back in swimming among the students of the third group control group where the value of $(\mathrm{T})$ the table between $(2.74$ To 3.99), which is greater than the value of the scale at the level of significance (0.05) and the researcher returns that result to the attendance at lectures, both practical or theoretical swimming.

In order to be able to push students to learn, Mousa Ibrahim, Adel Hassan (2003) points out that in order for the teacher to be able to use his students, he must use a variety of different methods and methods, which requires the teacher to be fully familiar with the different methods and methods of teaching and how students learn and how methods and methods affect Used to quickly achieve the goal of the teaching and learning process. $(21: 22)$

Steven Steven (2005) added that it is necessary for students to be familiar with the latest methods and techniques that enable them to communicate knowledge to learners and create better areas for improving the teaching and learning process. Hence, it is important to choose the appropriate teaching method to achieve the desired goal. The nature, components and variables of different educational situations (37:29)

The researcher attributed this progress to the control group to the regularity and continuation of practice and learning with the teacher to provide a series of exercises from easy to easy and difficult to practice from the student provided a good opportunity to learn the skills in question, which has a positive impact on the efficiency of skilled performance.

Thus, the second hypothesis of research was achieved, which states that there are statistically significant differences between the averages of preand post measurements in the level of cognitive achievement and learning some basic swimming skills among students of the control group

Table (5) shows statistically significant 
differences between mean distance measurements in the experimental and control groups at the level of some of the technical variables of swimming (crawling on the abdomen - crawling on the back where the tabular value (3.15 to 3.84) (0.05) indicating that the tutorial using the seven-stage learning dimensions model was more positive and effective on learning improvement and the performance of some swimming skills than the traditional tutorial (explanation and presentation) used by the control group. this result The proposed educational program took into consideration the abilities, needs and tendencies of the students, as well as the involvement of all their senses in the educational process, as well as giving them a positive role during the learning process. Which helped to build on their creativity and creativity.

The researcher also explained the difference between the two groups (control and experimental) in the level of skillful performance of some swimming skills that the learning program using the learning cycle helped the student to learn and master the skills (in search) as this technique is characterized by dividing each skill into small parts in light of the kinetic sequence (20) that strategies in teaching increase the impact of learning and acquire new skills for learners through which they learn. Helped to consolidate them in their minds, which is reflected on the learning process.

The researcher believes that the reason for the progress of the experimental group in the level of skilled performance in swimming from the control group that the use of the building cycle model has helped to attract the attention of students towards him, making the educational process more attractive and exciting and interesting them as a result of consulting their thinking positively and has helped them to work together They also heard discussion, dialogue and communication, helping them to have a desire to learn, and organizing their ideas sequentially to solve those questions in the basketball skills papers (in question), all of which reflected the progress of the 
ADA (17) that education is heavily influenced by the teaching methods used by the teacher during learning and therefore education based on the basis of experimentation and application is moving faster and easier than Traditional education The researcher also attributed this finding to the fact that the learning program using the seven-stage learning dimensions model helped to increase the level of student achievement of the facts, knowledge and information that helps to remember and understand the related material and clearly contributed to the achievement of educational goals.

This is also consistent with the study of Amira Mohammed Amir (2006) (1), Hala Qasim (2013) (25), which refers to the effectiveness of constructive learning, which leads to the interaction of learners with this method and challenge themselves and discover solutions to the problems and questions before them to reach Learn the skills under their research.

Thus, the third hypothesis of the research was achieved, which states that there are statistically significant differences between the two dimensions of the two dimensions of the experimental and control groups in the level of cognitive achievement and learning some basic skills in swimming and for the experimental research group.

\section{Conclusions}

-The use of modified ES-7 strategy has improved the level of learning to swim on the abdomen in the experimental group.

-The use of the revised strategy 7, ES, improved the level of swimming pool learning in the experimental group.

-The use of modified structural ES strategy 7 has improved the level of cognitive achievement of students in the experimental research group.

-The use of modified ES construct strategy improved the level of learning of the abdominal and back crawling classes and the cognitive achievement of the experimental group of students more than the control group and the user with the explanatory model.

\section{Recommendations}

-The use of modified strategy 7, ES because it has an 
effective role in improving the skill level in swimming.

-Using Strategy 7, ES structural change on different skills and stages in swimming. -The need to link knowledge and information within the continuous curriculum in water sports to improve the knowledge and knowledge of the female swimmers.

\section{References}

\section{1- Aisha Mohammed Al-Fateh} (2005): "The effectiveness of the use of constructive learning on the cognitive concepts and the level of performance of some attacks in the sport of fencing" unpublished doctoral thesis, Faculty of Physical Education for Girls, Helwan University, Cairo.

2 - Ali Abdul Majid (2000): "A proposed teaching strategy based on the model of constructive learning and its impact on the motor innovation of primary school students Research publication, the scientific journal Faculty of Physical Education for Boys, Helwan University, no. 33, April.

3- Amira Mohammed Amir (2011): the strategy of constructive learning using the hemisphere and its impact on the level of skill in volleyball, published scientific research, Journal of Science and Sports Arts, Faculty of Physical Education, Assiut University.

4- Amr Abdullah Abdul Qader Hussein (2004): "The impact of constructive learning in the teaching of basic skills of basketball," unpublished doctoral thesis, Faculty of Physical Education for Boys, Helwan University 12- Ayesh Zeitoun Al-Mawla (2007): The Theory of Constructivism and Strategies of Teaching Science, Dar Al-Shorouk, Cairo, 2007

5-Eisenkraft (2003). Expanding the 5E Model, " The science teacher" , vol .70, no.6 journal for high school science educators published by the national science teachers association

6- Duffy, T. M, \&Jonassen, D. H (2004): Constructivism new implicqrions for ins instructional technology Educational technology vol . 31 No .5

7- Hossam El-Din Nabih Abdel-Fattah (2005): "The effect of constructive learning method on the cognitive and emotional field and the level of skilled handball performance" $\mathrm{PhD}$ thesis- Faculty of Education- Al-Azhar University, Cairo. 
8- Hassan Hussein Zeitoun, Kamal Hussein Zeitoun (2003): "Education and teaching from the perspective of structural theory" World of the Book, Cairo

9- Jaber Abdul Hamid (2006): trends and contemporary experiences in evaluating the performance of the student and teacher, Dar Al - Fikr Al - Arabi, Cairo

\section{0- Kamal Abdel Hamid} Zaitoun (2002): "Teaching science for understanding (constructive vision)" World of Books Cairo.

11- Khairy Maghazi, Badir Ajaj (2000): "Methods of thinking and learning" comparative study, the AngloEgyptian Library, Cairo.

12- Majdi Aziz Ibrahim (2002): Effective teachingMahatah- skills- managementAnglo-Egyptian Library, Cairo, 2002.

13- Mai Talat (2011): "The effect of constructive learning on the memory of motor and the level of performance of some basketball skills" unpublished doctoral thesis, Faculty of Physical Education for Girls in Cairo Helwan University.

14-Makarem Helmi Abu Harja, Mohamed Saad Zaghloul Mahmoud and Hani
Said Abdel-Moneim (2001). Problems of Curricula of Physical Education School of Diagnosis and Treatment, AlKuttab Center for Publishing, Cairo.

\section{5- Mohamed Abdul Ghani} Osman (2003): Motor learning and sports training, second edition, Dar Al-Qalam, Kuwait.

16- Mohamed Ali Al-Sayyed (2002): Teaching aids and educational technology, 2, Dar Al-Fikr Al-Arabi, Cairo.

17- Mohamed Fathy ElKordany (2011): swimming, education, teaching, programs, the world of sports, Alexandria.

18- Musa Fahmy Ibrahim, Adel Ali Hassan (2003): Exercise and sports performances, Arab Thought House, Cairo.

19- Nabil Hussein Fadl, Fatima Rizk Atallah (2000): "Scientific Culture and Science Education, Arab Thought House, Cairo.

20- Noor Taha Ibrahim: (2014): Effect of the use of the course of learning dimensions 7 , ES structural modified at the level of learning some of the skills of mobility on the ground movements in the preparatory stage students, published scientific research, the scientific journal of physical education 
and mathematical sciences, Helwan University.

21- Noor Taha Ibrahim "The Effect of Using the Course of Learning Dimensions 7, Structural Adjustment ES on the Level of Skill Performance of Some Complex Attacking Skills in Karate Origin, published Scientific Research, Journal of Mathematical Sciences and Arts, Faculty of Physical Education for Boys, Helwan University.

22- Rasha Najaj Aly (2013) "Effect of using the constructional learning model on learning some of the kinetic skills of gymnastics sport for male students. Physical Education, Menia University, published scientific research, Journal of Mathematical Sciences, Faculty of Physical Education, Minia University.

23-Shaimaa Hassan Taha AlLeithi (2004): Modern techniques and their impact on the educational outcomes of the swimming pool, published research, Faculty of Sport Sports for Girls Helwan University, Journal of Sports Science and
Arts, Volume XX, Issue No. 1, January

\section{4- Smart Ibrahim Qas, Adel} Mahmoud Abdel-Hafez (2000): Methods of teaching in physical education, library and the printing press of artistic radiation, Alexandria

\section{5- Sumaya Mustafa Ahmed} (2001): "The strategy of constructive learning and its impact on the education of basketball skills and some cognitive outcomes of the students of the Faculty of Physical Education for Girls in Cairo" published research, the scientific journal of physical education and sports, No. 38, Cairo.

26-Walaa Shukri AbdelMoneim (2006): The Effect of Using Super Media on Swimming Learning, Master Thesis, Faculty of Sports Education for Girls, Cairo, Helwan University.

\section{7- Zeinab Ali Omar, Wafaa} Mufraj (2009): "Practical applications in teaching methods of physical education" Dar AlKitab Al-Hadith, Cairo. 